\title{
Atlantic Forest meets the Cerrado: floristic, structure and species distribution of an ecotonal tree community
}

\author{
Gabriel Pavan SABINO ${ }^{1 *}$, Vitor de Andrade KAMIMURA ${ }^{1,2}$, Gabriel Mendes MARCUSSO ${ }^{1}$, \\ Reinaldo MONTEIRO ${ }^{1}$
}

1 Departamento de Botânica, Universidade Estadual Paulista "Júlio de Mesquita Filho", Rio Claro, SP, Brasil.

${ }^{2}$ Departamento de Botânica, Universidade Federal de Minas Gerais, Belo Horizonte, MG, Brasil.

*E-mail: gpsabino@gmail.com

(ORCID: 0000-0003-1284-8781; 0000-0002-3276-5812; 0000-0002-7520-2876; 0000-0003-1019-6003)

Recebido em 08/07/2021; Aceito em 01/11/2021; Publicado em 11/11/2021.

\begin{abstract}
We evaluated the floristic and structural composition of a tree community in an ecotone between Cerrado (cerradão) and Atlantic Forest (seasonal semideciduous forest) domains located in Porto Ferreira State Park (PFSP), southeastern Brazil. We compared the floristic relationships of this ecotone with those of previous surveys carried out on the same vegetation types and checked the species distribution among the Brazilian biomes. We sampled all living trees with $\mathrm{PBH} \geq 10 \mathrm{~cm}$ in $6410 \mathrm{x} 10 \mathrm{~m}$ plots $(0.64 \mathrm{ha})$, totaling 1,755 individuals belonging to 101 species and 37 families. The richest families were Myrtaceae (13 spp.) and Fabaceae (11 spp.), and Siparuna guianensis was the most abundant species (188 individuals). We reported two threatened species. A great number of species are widely distributed, occurring in different Brazilian biomes. Floristic similarity values were low among the selected studies, but our sampled community clustered with communities of cerradão and ecotone areas of previous surveys. Our results corroborate that ecotonal areas have great tree diversity and the predominance of widely distributed species. This fact, combined with the vegetation thickening verified through historical photographs, reinforces that the study area belongs to an under-changing ecotone.
\end{abstract}

Keywords: ecotone; cerradão; seasonal semideciduous forest; phytogeography; floristic similarities.

\section{Mata Atlântica encontrando o Cerrado: florística, estrutura e distribuição de espécies de uma comunidade arbórea ecotonal}

\begin{abstract}
RESUMO: No presente estudo, avaliamos a composição florística e estrutura de uma comunidade arbórea de um ecótono entre o Cerrado (cerradão) e a Floresta Atlântica (floresta estacional semidecidual) localizado no Parque Estadual de Porto Ferreira (PEPF), sudeste do Brasil. Verificamos também as relações florísticas com outros levantamentos realizados nestas fitofisionomias, e analisamos a distribuição das espécies nos domínios fitogeográficos brasileiros. Para isso amostramos todos os indivíduos vivos com PAP $\geq 10 \mathrm{~cm}$ em 64 parcelas de 10x10m (0,64 ha), totalizando 1755 indivíduos pertencentes a 101 espécies e 37 famílias. As famílias mais ricas em espécies foram Myrtaceae (13 espécies) e Fabaceae (11) sendo Siparuna guianensis a espécie mais abundante (188 indivíduos). Registramos duas espécies ameaçadas de extinção e verificamos um grande número de espécies com ampla distribuição entre os domínios fitogeográficos do Brasil. Encontramos baixos valores de similaridade florísticas entre as áreas analisadas, e a comunidade amostrada apresentou maior similaridade com levantamentos realizados em área de cerradão e ecótonos. Em síntese, os resultados corroboram a grande diversidade arbórea de áreas ecotonais, e o predomínio de espécies com ampla distribuição. Esse fato associado ao adensamento da vegetação verificado em série fotográfica histórica, reforçam que a área do estudo pertence a um ecótono em transformação.

Palavras-chave: ecótono; cerradão; floresta estacional semidecidual; fitogeografia; similaridade florísticas.
\end{abstract}

\section{INTRODUCTION}

Ecotones (gr. tonus $=$ tension) are transitional areas between ecological communities that commonly occur along environmental gradients (ORCZEWSKA; GLISTA, 2005). Studies have reported high species richness and abundance tendency for ecotonal areas (e.g., KARK; van RENSBURG, 2006). Ecotones play an important role since environmental gradients are important speciation and diversification sites (SCHILTHUIZEN, 2000; SCHLUTER, 2000; SMITH et al., 2001). The preservation of such areas can guarantee adaptive responses of species to climate change (SMITH et al., 2001).

Savannah and forest ecotones play an important ecological role in the tropics (HOFFMANN, 2005). Mosaics of savannah-forest transitions occupy about $24 \%$ of the Cerrado domain in Brazil (SILVA; BATES, 2002), and several studies have pointed to edaphic factors as decisive drivers of the establishment of Cerrado (savannah) and Atlantic Forest physiognomies (FURLEY, 1992; RATTER, 1992; DURIGAN; RATTER, 2006; PINHEIRO; MONTEIRO, 2008; BARROS et al. 2018; PINHEIRO et al. 2021). Furley (1992) concluded that soil moisture is a determining factor in savannah-forest transitions. For Ratter (1992), the soil is the main factor that influences the geographic distribution of vegetation. Furthermore, fire suppression can change the Cerrado vegetation types, since 
forest vegetation types can replace open vegetations over the years (DURIGAN; RATTER, 2006; PINHEIRO et al., 2021). On the other hand, the presence of fire can facilitate the invasion of savannah species in seasonal semideciduous forests (PINHEIRO; MONTEIRO, 2008).

Sauer (1988) claims that there is a balance in savannahforest ecotones in South America. However, several studies have shown a movement of these phytocenoses and an expansion of forest formations over areas previously occupied by Cerrado vegetation types (COUTINHO, 1990; RATTER, 1992; PIVELLO; COUTINHO, 1996; DURIGAN; RATTER, 2006; PINHEIRO; MONTEIRO, 2021).

Floristic and structural studies have been carried out on Cerrado and seasonal semideciduous forests of southeastern Brazil (DURIGAN et al., 1994; IVANAUSKAS et al. 1999; DURIGAN et al. 2002; TEIXEIRA et al. 2004; NETO et al., 2009; PINHEIRO \& DURIGAN, 2012; HENCKER et al., 2012; GARCIA et al., 2015), but few of them have encompassed transitional areas (e.g., PINHEIRO; MONTEIRO, 2008; GUILHERME; NAKAJIMA, 2007; GOMES et al., 2004). Thus, we still do not understand this complex mosaic completely. Data about transitional areas are the basis for restoration projects, considering their importance for legal activities for environmental adaptations and licensing processes (e.g., Degraded Areas Recovery Plan - PRAD). Furthermore, floristic relationships of these ecotonal areas are important for characterizing and contextualizing vegetations under its transitional condition.

In this study, we evaluate the composition, structure, species distribution, and phytogeographic relationships of the tree community of an ecotonal area to support recovery, restoration and conservational actions in Cerrado-Atlantic Forest ecotones in São Paulo state.

\section{MATERIALS E METHODS}

\subsection{Study area}

The study was conducted in an area with a cerradão (CER) vegetation, a forested savannah, in transition with a seasonal semideciduous forest (SSF) in Porto Ferreira State Park (PFSP), municipality of Porto Ferreira, São Paulo state, southeastern Brazil (Figure 1). Plots were placed in an area at the north of "Lagoa do Cerrado" (2150'49"S, 47²5'39"W), where the average altitude was $600 \mathrm{~m}$. The region's climate is classified as Cwa, or mesothermal dry winter, according to the Köppen-Geiger scale (Alvares et al., 2013). The annual mean temperature and precipitation are $22^{\circ} \mathrm{C}$ and $1470 \mathrm{~mm}$, respectively, with a well pronounced dry winter (INMET, 2020).

The PFSP is composed of different vegetation types. CER is predominant in the north and SSF in the south of PFSP (Rossi et al., 2005). At the southernmost limit of the PFSP, parallel to the Mogi Guaçu River, the predominant vegetation type is the riparian forest (KONOPCZYK, 2014). CER occupies an area of about 180 ha, where the topography is higher (Bertoni et al., 2001). The study area has a secondary vegetation that has greatly recovered its structure, as evidenced by the sequential aerial photographs taken in the 1960s, 1970s, and 1980s (Figure 2).

\subsection{Sampling and species distribution}

We sampled 64 plots with $10 \times 10 \mathrm{~m}$ (totalizing $0.64 \mathrm{ha}$ ), alternately placed along eight transects (with eight plots each).
The delimitation of transects and plots was made by using timber stakes and cotton strings. We sampled all living trees and palms with a perimeter at breast height $(\mathrm{PBH}) \geq 10 \mathrm{~cm}$. The botanical material was identified by consulting specialized bibliography and taxonomic specialists and by comparing it with materials deposited in the Herbario Rioclarense (HRCB) collection. Fertile material was deposited in the HRCB collection. Taxa classification followed APG IV (2016) and the nomenclature was updated according to Flora do Brasil (Flora do Brasil, 2020), The Plant List (2020), and Tropicos (2020). We assessed the threatened status of the species sampled following the Livro Vermelho da Flora do Brasil (MARTINELLI; MORAES, 2013).

For phytosociological analysis, we recorded the $\mathrm{PBH}$ values and the height of each individual sampled. We assessed the natural distribution of the species in Brazilian biomes according to Flora do Brasil 2020 (2020). Species occurring in four or more biomes were classified as "widely distributed".

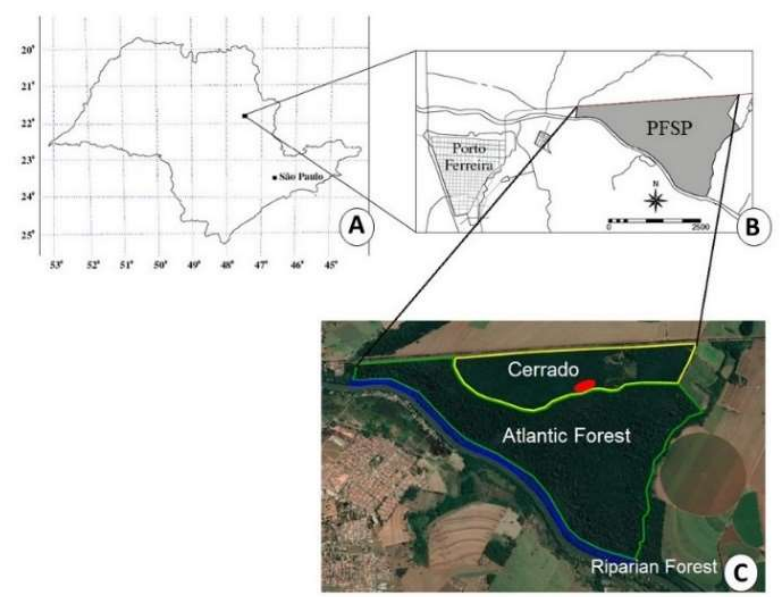

Figure 1. Location of Porto Ferreira State Park (PFSP), Porto Ferreira, São Paulo state. A- study site in São Paulo state map; BPFSP; C- vegetation types of PFSP. Red ellipse indicates the site of the study plots.

Figura 1. Localização do Parque Estadual de Porto Ferreira (PEPF), Porto Ferreira, estado de São Paulo. A- Local de estudo no mapa do estado de São Paulo; B - PEPF; C- fitofisionomias do PEPF. A elipse vermelha indica a localização das parcelas do estudo.

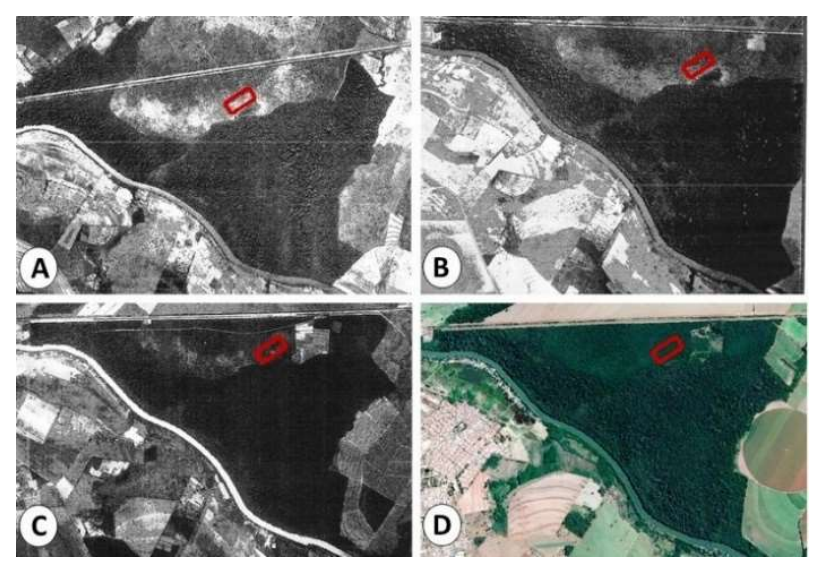

Figura 2. Fotografias aéreas do Parque Estadual de Porto Ferreira. A- de 1962; B- de 1971; C- de 1983; D- imagem de satélite de 2020 (Google Earth(C). Retângulos vermelhos indicam a localização das parcelas do estudo.

Figure 2. Aerial photographs of Porto Ferreira State Park. A- from 1962; B- from 1971; C- from 1983; D- satellite image from 2020 (Google Earth(C). Red rectangles indicate the site of the study plots. 
We compiled 19 studies previously carried out on CER, cerrado sensu stricto, SSF, and ecotones including one of these vegetation types (Table 1). Only native shrub and tree taxa identified at the species level were considered (if the study included more life forms).

\subsection{Data analysis}

Phytosociological parameters such as relative frequency, dominance, and importance value were calculated following Shepherd (2008). We also estimated the Shannon diversity index $\left(\mathrm{H}^{\prime}\right)$ and Pielou equability $\left(\mathrm{J}^{\prime}\right)$. Finally, to assess sample sufficiency, we performed a species accumulation curve (SAC) to compute the mean SAC and its standard deviation from 999 random permutations of the data (GOTELLI; COLWELL, 2001).

We conducted a cluster analysis to assess floristic similarity among the compiled studies and the present study. We built a binary matrix with the presence (1) and absence (0) of all species and conducted an agglomerative hierarchical cluster analysis (UPGMA) using the Jaccard dissimilarity index (LEGENDRE; LEGENDRE, 2012). Then, we verified exclusive and shared species among the studies carried out on ecotones.

All analyses were conducted in $\mathrm{R}$ software ( $\mathrm{R}$ Development Core Team, 2020) using the 'vegan' package (OKSANEN et al., 2013).

Table 1. Selected studies for the floristic similarity analysis. Co: Code; Ph: physiognomy; N: number of taxons included in similarity analysis; Nt: total number of taxons; St. R. do P. Quatro: Santa Rita do Passa Quatro; S.B. do Campo: São Bernardo do Campo; Ssf: seasonal semideciduous forest; Eco: ecotone; Cd: cerradão; C ss: cerrado sensu stricto.

Tabela 1. Estudos selecionados para a análise de similaridade florística. Co: Código; Ph: fisionomia; N: número de táxons utilizados na análise de similaridade; Nt: Número total de táxons; St. R. do P. Quatro: Santa Rita do Passa Quatro; S.B. do Campo: São Bernardo do Campo; Ssf: floresta estacional semidecidual; Eco: ecótono; Cd: cerradão; C ss: cerrado sensu stricto.

\begin{tabular}{clccc}
\hline Co & Study Site & Ph. & N / Nt & REFERENCE \\
\hline A & Porto Ferreira - SP & Eco & $87 / 101$ & Present study \\
B & Bauru - SP & Eco & $223 / 264$ & Pinheiro \& Monteiro, 2008 \\
C & Brotas - SP & Eco & $116 / 125$ & Gomes et al., 2004 \\
D & Uberlandia - MG & Eco & $121 / 141$ & Guilherme \& Nakajima, 2007 \\
E & Viçosa - MG & Ssf & $93 / 107$ & Ribas et al., 2003 \\
F & Campinas - SP & Ssf & $132 / 362$ & Bernacci \& Leitão, 1996 \\
G & Campinas - SP & Ssf & $135 / 201$ & Guaratini et al., 2008 \\
H & St. R. do P. Quatro - SP & Ssf & $56 / 56$ & Bertoni et al., 1988 \\
I & St. R. do P. Quatro-SP & Ssf & $59 / 81$ & Vieira et al., 1989 \\
J & Itatinga - SP & Ssf & $87 / 97$ & Ivanauskas et al., 1999 \\
K & S. B. do Campo-SP & Ssf & $70 / 75$ & Pastore et al., 1992 \\
L & São Carlos - SP & Ssf & $123 / 146$ & Silva \& Soares, 2003 \\
M & Águas da Prata - SP & Ssf & $117 / 126$ & Toledo Filho et al., 1993 \\
N & Uberlândia - MG & Cd & $73 / 74$ & Alves et al., 2013 \\
O & St. R. do P. Quatro-SP & Cd & $81 / 148$ & Batalha \& Mantovani, 2001 \\
P & Luís Antonio - SP & Cd & $89 / 121$ & Silva et al., 2004 \\
Q & Bauru - SP & Cd & $126 / 135$ & Pinheiro \& Monteiro, 2006 \\
R & Mogi mirim - SP & Cd & $88 / 104$ & Toledo Filho et al., 1989 \\
S & Uberlândia - MG & Cd, C ss & $103 / 107$ & Costa \& Araújo, 2001 \\
T & Paraopeba - MG & Cd, C ss & $81 / 91$ & Campos et al., 2006 \\
\hline
\end{tabular}

\section{RESULTS}

We surveyed 1,755 trees and palms. We reported 101 species distributed in 37 botanical families and 69 genera (Table 2). Euterpe edulis Mart. (Arecaceae) and Cedrela fissilis Vell. (Meliaceae) were classified as "vulnerable" according to the list of threatened species of the Livro Vermelho da Flora do Brasil (Martinelli \& Moraes, 2013). The Shannon-Wiener diversity index was 3.65 nats/ind., and the Pielou equability index was 0.79 .

The richest species families were Myrtaceae (13 spp.), Fabaceae (11 spp.), Annonaceae (6 spp.), Anacardiaceae (5 spp.), Melastomataceae, Rubiaceae, Euphorbiaceae, and Lauraceae (4 spp. each). Altogether, these families comprised $50.4 \%$ of the species recorded and $54.3 \%$ of the individuals sampled. Fifteen families were represented by a single species, and 27 species were represented by a single individual. Lauraceae was the family with the highest importance value $(\mathrm{IV}=28.9)$, followed by Anacardiaceae $(\mathrm{IV}=28.5)$, and Fabaceae $(\mathrm{IV}=24.7)$.

Among the species, Tapirira guianensis Aubl. showed the highest importance value $(\mathrm{IV}=20)$, followed by Miconia affinis
DC. $(\mathrm{IV}=18.7)$ and Siparuna guianensis Aubl. (IV= 18.4). Siparuna guianensis was the most abundant species (188 individuals, $10.7 \%$ of the total amount of species) followed by $M$. affinis (154 individuals, 8.7\%), and Xylopia aromatica (Lam.) Mart. (113 individuals, 6.4\%). According to the species accumulation curve, the sample size of our study was sufficient to discuss differences among the areas (Figure 3).

The total basal area of the individuals was $11.65 \mathrm{~m}^{2}$. The mean height was $6.6 \mathrm{~m}$ (standard deviation= 2.9), with minimum and maximum values of 1.9 and $22 \mathrm{~m}$, respectively. The mean diameter was $7.4 \mathrm{~cm}$ (standard deviation= 5.3), with minimum and maximum values of $3.18 \mathrm{~cm}$ and 58.27 $\mathrm{cm}$, respectively.

Out of the 101 species reported in this study, $87(1,703$ individuals) were identified at the species level and classified based on their distribution among the Brazilian biomes. Of this total, 38 species (44\%) were classified as "widely distributed", and together they included 713 individuals (41.8\%). Only five species $(6 \%)$ and 31 individuals $(1.8 \%)$ are restricted to the Atlantic Forest. Likewise, six species $(7 \%)$ and 147 individuals $(8.6 \%)$ are restricted to 
Cerrado. Also, 31 species (36\%) and 670 individuals (39.3\%) are reported for both Cerrado and Atlantic Forest.

The total amount of 644 species were sampled from the 20 lists chosen for the floristic similarity, of which 244 $(37.8 \%)$ have been reported exclusively in a single study (appendix 1). Only 26 species (4\%) occurred in 50\% or more of the lists (Appendix 2), and no species were recorded for all areas.

Among the ecotonal lists (A-D, Table 1), 341 species were reported, of which $215(63 \%)$ has exclusive occurrence (appendix 3), $126(36.9 \%)$ occur in $50 \%$ or more of the 4 lists, and 19 species were reported for all areas (appendix 4).

The similarity analysis showed a high coefficient of cophenetic correlation (0.91), and floristic similarities were higher among closer areas. The cluster analysis segregated two major floristic groups (Figure 4). The first group (1) clustered the studies carried out on CER and ecotones, including the present study; the second (2) clustered the studies carried out on SSF.

Table 2. Floristic list, structural parameters, and biomes of occurrence of an ecotonal tree community, Porto Ferreira State Park, municipality of Porto Ferreira, São Paulo State, southeastern Brazil. Abd: abundance; RelDo: relative dominance; RelFr: relative frequency; IV: importance value; WD: widely distributed; Cer: Cerrado; AF: Atlantic Forest; Am: Amazon; Pa: Pampa; Caa: Caatinga; Pn: Pantanal; “\”: not evaluated; asterisks indicate threatened species according to "Livro Vermelho da Flora do Brasil" by CNCFlora (Martinelli \& Moraes, 2013).

Tabela 2. Lista florística, parâmetros estruturais e ocorrência das espécies nos domínios fitogeográficos de uma comunidade arbórea ecotonal, Parque Estadual de Porto Ferreira, cidade de Porto Ferreira, Estado de São Paulo, Sudeste do Brasil. Abd: abundância; RelDo: dominância relativa; RelFr: frequência relativa; IV: valor de importância; WD: ampla distribuição; Cer: Cerrado; AF: Mata Atlântica; Am: Amazônia; Pa: Pampa; Caa: Caatinga; Pn: Pantanal; “””: não avaliado; asteriscos indicam espécies ameaçadas de acordo com o "Livro Vermelho da Flora do Brasil", CNCFlora (Martinelli \& Moraes, 2013).

\begin{tabular}{|c|c|c|c|c|c|c|}
\hline Family & Species & Abd & RelDo & RelFr & IV & Biomes \\
\hline \multirow[t]{5}{*}{ Anacardiaceae } & Astronium graveolens Jacq. & 7 & 0.21 & 0.71 & 1.32 & WD \\
\hline & Astronium urundeuva (M.Allemão) Engl. & 1 & 0.04 & 0.1 & 0.2 & WD \\
\hline & Lithraea molleoides (Vell.) Engl. & 1 & 0.02 & 0.1 & 0.18 & WD \\
\hline & Tapirira guianensis Aubl. & 82 & 11.01 & 4.34 & 20.02 & WD \\
\hline & Tapirira obtusa (Benth.) J.D.Mitch. & 26 & 4.34 & 1.72 & 7.53 & Cer, AF, Am \\
\hline \multirow[t]{6}{*}{ Annonaceae } & Annona sylvatica A.St.-Hil. & 1 & 0.02 & 0.1 & 0.18 & WD \\
\hline & Annona sp. & 1 & 0.05 & 0.1 & 0.21 & $\backslash$ \\
\hline & Duguetia lanceolata A.St.-Hil. & 4 & 0.16 & 0.4 & 0.79 & Cer, AF \\
\hline & Xylopia aromatica (Lam.) Mart. & 113 & 4.13 & 4.34 & 14.91 & Cer, Am \\
\hline & Xylopia brasiliensis Spreng. & 2 & 0.11 & 0.2 & 0.42 & $\mathrm{AF}$ \\
\hline & Xylopia sericea A.St.-Hil. & 25 & 1.15 & 1.72 & 4.29 & Cer, AF, Am \\
\hline Apocynaceae & Aspidosperma sp. & 1 & 0.04 & 0.1 & 0.2 & $\backslash$ \\
\hline \multirow[t]{2}{*}{ Araliaceae } & Dendropanax cuneatus (DC.) Decne. \& Planch. & 1 & 0.04 & 0.1 & 0.19 & WD \\
\hline & Didymopanax morototoni (Aubl.) Decne. \& Planch. & 17 & 0.7 & 1.41 & 3.08 & WD \\
\hline \multirow[t]{3}{*}{ Arecaceae } & Acrocomia aculeata (Jacq.) Lodd. ex Mart. & 1 & 0.3 & 0.1 & 0.46 & Cer, AF \\
\hline & Euterpe edulis Mart. * & 1 & 0.03 & 0.1 & 0.19 & Cer, AF \\
\hline & Syagrus romanzoffiana (Cham.) Glassman & 27 & 5.34 & 1.92 & 8.8 & Cer, AF, Pa \\
\hline Asteraceae & Piptocarpha macropoda (DC.) Baker & 2 & 0.04 & 0.2 & 0.35 & Cer, AF \\
\hline \multirow[t]{2}{*}{ Bignoniaceae } & Handroanthus ocbraceus (Cham.) Mattos & 3 & 0.07 & 0.2 & 0.44 & WD \\
\hline & Handroanthus vellosoi (Toledo) Mattos & 11 & 0.91 & 1.01 & 2.55 & $\mathrm{AF}$ \\
\hline Burseraceae & Protium heptaphyllum (Aubl.) Marchand & 4 & 0.17 & 0.2 & 0.6 & WD \\
\hline Calophyllaceae & Calophyllum brasiliense Cambess. & 1 & 0.02 & 0.1 & 0.17 & WD \\
\hline Clethraceae & Clethra scabra Pers. & 2 & 0.12 & 0.2 & 0.43 & Cer, AF, Caa \\
\hline \multirow[t]{2}{*}{ Combretaceae } & Terminalia argentea Mart. \& Zucc. & 3 & 0.19 & 0.3 & 0.66 & WD \\
\hline & Terminalia glabrescens Mart. & 42 & 1.88 & 2.02 & 6.29 & WD \\
\hline \multirow[t]{4}{*}{ Euphorbiaceae } & Alchornea glandulosa Poepp. \& Endl. & 2 & 0.7 & 0.2 & 1.02 & Cer, AF, Am \\
\hline & Croton floribundus Spreng. & 10 & 0.9 & 0.91 & 2.38 & $\mathrm{AF}$ \\
\hline & Maprounea guianensis Aubl. & 59 & 2.44 & 3.63 & 9.44 & Cer, AF, Am \\
\hline & Sebastiania sp. & 3 & 0.15 & 0.3 & 0.62 & $\backslash$ \\
\hline \multirow[t]{11}{*}{ Fabaceae } & Andira anthelmia (Vell.) Benth. & 4 & 0.13 & 0.2 & 0.56 & Cer, $\mathrm{AF}$ \\
\hline & Andira bumilis Mart. ex Benth. & 1 & 1 & 0.1 & 1.15 & Cer \\
\hline & Copaifera langsdorffii Desf. & 61 & 9.27 & 2.72 & 15.47 & WD \\
\hline & Dimorphandra mollis Benth. & 1 & 0.21 & 0.1 & 0.36 & Cer, Am, Pn \\
\hline & Inga striata Benth. & 1 & 0.09 & 0.1 & 0.25 & WD \\
\hline & Leptolobium dasycarpum Vogel & 1 & 0.06 & 0.1 & 0.22 & Cer \\
\hline & Machaerium aculeatum Raddi & 6 & 0.3 & 0.61 & 1.25 & Cer, AF, Pn \\
\hline & Machaerium villosum Vogel & 5 & 0.29 & 0.5 & 1.08 & WD \\
\hline & Peltophorum dubium (Spreng.) Taub. & 1 & 0.01 & 0.1 & 0.17 & WD \\
\hline & Platypodium elegans Vogel & 9 & 1.88 & 0.71 & 3.09 & WD \\
\hline & Senegalia polyphylla (DC.) Britton \& Rose & 12 & 0.22 & 0.81 & 1.72 & WD \\
\hline Lacistemataceae & Lacistema hasslerianum Chodat & 6 & 0.07 & 0.61 & 1.02 & Cer \\
\hline Lamiaceae & Aegiphila integrifolia (Jacq.) Moldenke & 3 & 0.2 & 0.3 & 0.67 & WD \\
\hline
\end{tabular}


Sabino et al.

\begin{tabular}{|c|c|c|c|c|c|c|}
\hline Family & Species & Abd & RelDo & RelFr & IV & Biomes \\
\hline \multirow[t]{4}{*}{ Lauraceae } & Ocotea corymbosa (Meisn.) Mez & 77 & 7.47 & 4.24 & 16.1 & Cer, AF \\
\hline & Ocotea nutans (Nees) Mez & 24 & 0.66 & 1.92 & 3.94 & Cer, AF \\
\hline & Ocotea pulchella (Nees \& Mart.) Mez & 59 & 4.22 & 3.83 & 11.42 & Cer, $\mathrm{AF}, \mathrm{Pa}$ \\
\hline & Ocotea velutina (Nees) Rohwer & 1 & 0.29 & 0.1 & 0.45 & Cer, AF \\
\hline \multirow[t]{2}{*}{ Malpighiaceae } & Byrsonima intermedia A.Juss. & 85 & 3.93 & 4.04 & 12.81 & Cer \\
\hline & Byrsonima sp. & 3 & 0.13 & 0.3 & 0.6 & $\backslash$ \\
\hline \multirow[t]{3}{*}{ Malvaceae } & Luehea divaricata Mart. & 2 & 0.03 & 0.2 & 0.35 & WD \\
\hline & Luebea grandiflora Mart. & 4 & 0.92 & 0.4 & 1.55 & WD \\
\hline & Pseudobombax grandiflorum (Cav.) A.Robyns & 7 & 0.42 & 0.4 & 1.22 & $\mathrm{AF}$ \\
\hline \multirow[t]{4}{*}{ Melastomataceae } & Miconia affinis DC. & 154 & 4.86 & 5.15 & 18.78 & Cer, AF, Am \\
\hline & Miconia ligustroides (DC.) Naudin & 3 & 0.12 & 0.3 & 0.6 & Cer, AF, Caa \\
\hline & Miconia rubiginosa (Bonpl.) DC. & 1 & 0.02 & 0.1 & 0.17 & Cer, Am \\
\hline & Tiboucbina sp. & 1 & 0.01 & 0.1 & 0.17 & $\backslash$ \\
\hline \multirow[t]{3}{*}{ Meliaceae } & Cedrela fissilis Vell. * & 2 & 0.11 & 0.2 & 0.42 & WD \\
\hline & Trichilia casaretti C.DC. & 5 & 0.07 & 0.3 & 0.66 & Cer, AF \\
\hline & Tricbilia pallida Sw. & 44 & 1.19 & 2.22 & 5.92 & Cer, AF, Am \\
\hline \multirow[t]{2}{*}{ Moraceae } & Ficus guaranitica Chodat & 6 & 0.14 & 0.61 & 1.08 & Cer, AF \\
\hline & Maclura tinctoria (L.) D.Don ex Steud. & 1 & 0.01 & 0.1 & 0.17 & WD \\
\hline Myristicaceae & Virola sebifera Aubl. & 17 & 0.73 & 1.41 & 3.11 & Cer, AF, Am \\
\hline \multirow[t]{13}{*}{ Myrtaceae } & Eugenia florida DC. & 6 & 0.09 & 0.61 & 1.04 & WD \\
\hline & Eugenia sp. & 1 & 0.42 & 0.1 & 0.58 & 1 \\
\hline & Myrcia bella Cambess. & 35 & 2.01 & 2.02 & 6.03 & Cer \\
\hline & Myria guianensis (Aubl.) DC. & 19 & 0.69 & 1.31 & 3.08 & WD \\
\hline & Myria sp. & 24 & 0.41 & 1.51 & 3.29 & $\backslash$ \\
\hline & Myrcia splendens (Sw.) DC. & 11 & 0.19 & 1.01 & 1.82 & WD \\
\hline & Myria tomentosa (Aubl.) DC. & 20 & 0.72 & 1.61 & 3.47 & WD \\
\hline & Myrcia venulosa DC. & 10 & 0.22 & 1.01 & 1.8 & Cer, AF \\
\hline & Myriaria sp. & 2 & 0.03 & 0.2 & 0.34 & $\backslash$ \\
\hline & Myrtaceae 1 & 1 & 0.01 & 0.1 & 0.16 & 1 \\
\hline & Myrtaceae 2 & 2 & 0.02 & 0.1 & 0.23 & 1 \\
\hline & Myrtaceae 3 & 1 & 0.02 & 0.1 & 0.18 & 1 \\
\hline & Psidium rufum Mart. ex DC. & 15 & 0.79 & 1.11 & 2.75 & Cer, AF \\
\hline Ochnaceae & Ouratea castaneifolia (DC.) Engl. & 2 & 0.2 & 0.2 & 0.51 & WD \\
\hline Peraceae & Pera glabrata (Schott) Baill. & 45 & 2.69 & 2.42 & 7.67 & WD \\
\hline \multirow[t]{2}{*}{ Primulaceae } & Myrsine coriacea (Sw.) R.Br. ex Roem. \& Schult. & 16 & 0.5 & 1.61 & 3.03 & Cer, $\mathrm{AF}, \mathrm{Pa}$ \\
\hline & Myrsine umbellata Mart. & 100 & 3.33 & 4.54 & 13.57 & WD \\
\hline Proteaceae & Roupala montana Aubl. & 1 & 0.01 & 0.1 & 0.17 & WD \\
\hline Rosaceae & Prunus myrtifolia (L.) Urb. & 3 & 0.06 & 0.3 & 0.54 & WD \\
\hline \multirow[t]{4}{*}{ Rubiaceae } & Amaioua guianensis Aubl. & 21 & 0.47 & 1.72 & 3.38 & Cer, AF, Am \\
\hline & Cordiera sessilis (Vell.) Kuntze & 11 & 0.16 & 0.91 & 1.7 & Cer, Caa \\
\hline & Ixora brevifolia Benth. & 15 & 1.38 & 1.31 & 3.55 & Cer, Caa \\
\hline & Rudgea viburnoides (Cham.) Benth. & 1 & 0.02 & 0.1 & 0.18 & Cer, Caa, Am \\
\hline Rutaceae & Zanthoxylum rhoifolium Lam. & 2 & 0.14 & 0.2 & 0.46 & WD \\
\hline \multirow[t]{3}{*}{ Salicaceae } & Casearia gossypiosperma Briq. & 4 & 0.19 & 0.3 & 0.72 & Cer, AF, Am \\
\hline & Casearia sp. & 1 & 0.01 & 0.1 & 0.16 & 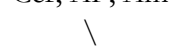 \\
\hline & Casearia sylvestris $\mathrm{Sw}$ & 29 & 0.79 & 1.92 & 4.36 & WD \\
\hline \multirow[t]{3}{*}{ Sapindaceae } & Allophylus semidentatus (Miq.) Radlk. & 1 & 0.02 & 0.1 & 0.18 & Cer, AF, Am \\
\hline & Cupania vernalis Cambess. & 9 & 0.2 & 0.81 & 1.52 & WD \\
\hline & Matayba sp. & 10 & 0.77 & 0.81 & 2.15 & $\backslash$ \\
\hline \multirow[t]{2}{*}{ Sapotaceae } & Chrysophyllum marginatum (Hook. \& Arn.) Radlk. & 9 & 0.41 & 0.71 & 1.63 & WD \\
\hline & Pouteria sp. & 1 & 0.03 & 0.1 & 0.19 & $\backslash$ \\
\hline Siparunaceae & Siparuna guianensis Aubl. & 188 & 2.18 & 5.55 & 18.44 & WD \\
\hline \multirow[t]{3}{*}{ Styracaceae } & Styrax acuminatus Pohl & 1 & 0.03 & 0.1 & 0.19 & $\mathrm{AF}$ \\
\hline & Styrax camporum Pohl & 16 & 0.71 & 1.51 & 3.13 & Cer, AF, Caa \\
\hline & Styrax ferrugineus Nees \& Mart. & 2 & 0.06 & 0.2 & 0.38 & Cer \\
\hline Urticaceae & Cecropia pachystachya Trécul & 5 & 0.19 & 0.4 & 0.88 & WD \\
\hline \multirow[t]{3}{*}{ Vochysiaceae } & Qualea cordata Spreng. & 7 & 0.54 & 0.71 & 1.64 & Cer, AF, Caa \\
\hline & Qualea grandiflora Mart. & 17 & 1.67 & 1.41 & 4.06 & Cer \\
\hline & Vochysia tucanorum Mart. & 31 & 3.32 & 1.31 & 6.4 & Cer, AF \\
\hline
\end{tabular}




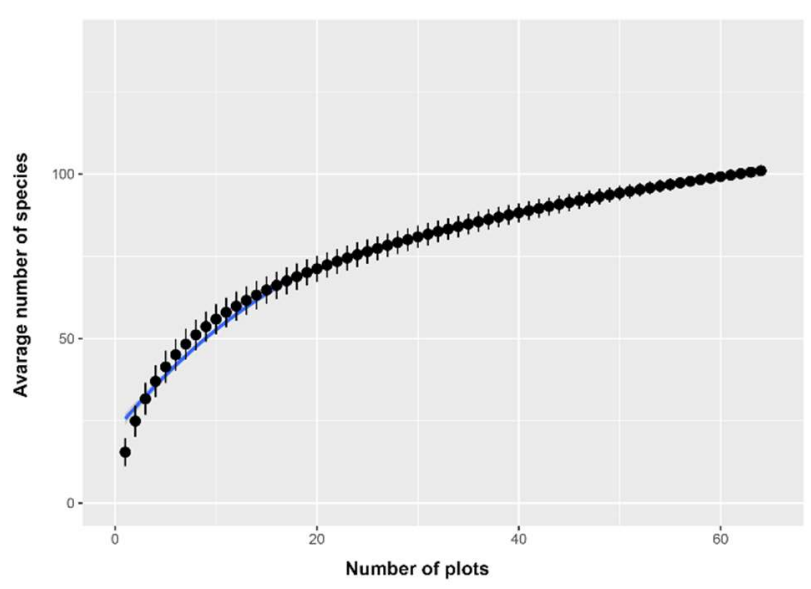

Figure 3. Species accumulation curve generated by using the sampling random method for the tree community surveyed in the ecotonal area of Porto Ferreira State Park, Porto Ferreira, Brazil.

Figura 3. Curva de acumulação de espécies geradas para a comunidade arbórea amostrada em área ecotonal, Parque Estadual de Porto Ferreira, Porto Ferreira, Brasil.

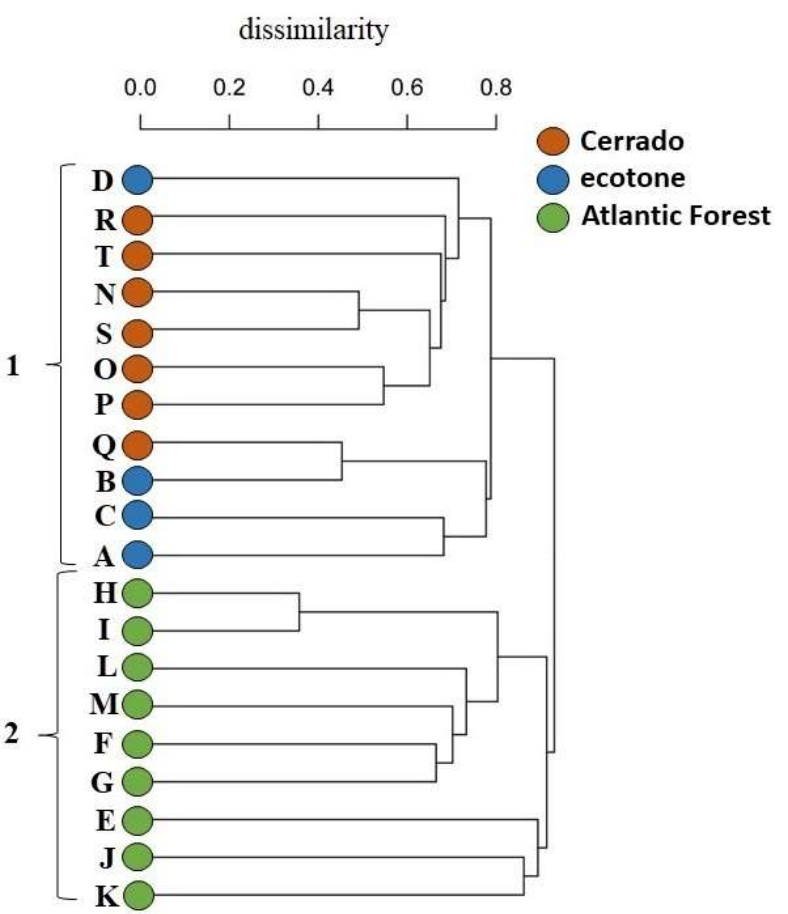

Figure 4. Cluster analysis (UPGMA), using Jaccard's index, of 20 studies carried out on Cerrado, Atlantic Forest, and ecotones. A the present study. A-T - previous selected studies. The list of the selected studies is given in Table 1.

Figura 4. Análise de agrupamento (UPGMA) usando o índice de Jaccard entre 20 estudos conduzidos no Cerrado, Mata Atlântica e ecótonos. Letra A- presente estudo. Estudos (identificados pelas letras A-T) estão disponíveis na tabela 1.

\section{DISCUSSION}

The tree diversity we found in this survey was similar from what was found in previous studies carried out on Cerrado (Toledo Filho et al.,1989; Costa \& Araújo, 2001; Silva et al., 2004), SSF (Vieira et al., 1989; Ivanauskas et al., 1999), and ecotones (Gomes et al., 2004; Guilherme; Nakajima, 2007). However, diversity comparisons should be made with caution, given the differences in inclusion criteria and sample sizes among the studies. Studies encompassing a big range of life forms (e.g., Bernacci; Leitão, 1996; Batalha; Mantovani, 2001; Guaratini et al., 2008; Pinheiro; Monteiro, 2008) naturally show a greater number of species.

The diversity value (3.65) found in the present study site is higher than those of studies on CER (which range from 2.46 to 3.54) (Costa; Araújo, 2001; Alves et al., 2013) and higher than the expected for SSF (ranging from 3.45 to 3.77) (Ivanauskas, 1999; Silva; Soares, 2003), and ecotone sites (ranging from 3.37 to 3.99) (Gomes et al., 2004; Guilherme; Nakajima, 2007). This shows that the diversity in transitional areas can be greater than what has been found in underlying vegetation types.

The richest families of tree species corroborate the results found for CER (Silva et al., 2004; Campos et al., 2006), SSF (Bernacci; Leitão, 1996; Ivanauskas et al., 1999; Guaratini et al., 2008), and ecotones (Gomes et al., 2004; Guilherme; Nakajima, 2007; Pinheiro; Monteiro, 2008). In SSF surveys, Fabaceae and Myrtaceae are often the richest families (Vieira et al., 1989; Bernacci; Leitão, 1996; Ivanauskas et al., 1999; Guaratini et al., 2008). Anacardiaceae is the only family of our list rarely ranked among the most diverse family in other studies. In Atlantic Forest, Myrtaceae, Fabaceae, Melastomataceae, Rubiaceae, and Euphorbiaceae are among the 10 richest families (BFG, 2015). These families are also among the richest families in Cerrado, except for Myrtaceae (BFG, 2015).

Lauraceae was the family with the highest importance value $(\mathrm{IV}=9.64 \%)$ due to the large dimensions of the individuals and the abundance of Ocotea corymbosa and Ocotea pulchella. Likewise, Anacardiaceae showed the second highest IV $(9.5 \%)$ due to the great number of individuals of Tapirira guianensis and Tapirira obtusa surveyed and their big sizes.

Many species were represented by a few individuals, corroborating the distribution pattern of individuals of tropical forest species (HUBBEL, 2013). In that sense, 45 species were represented by three or fewer individuals, 27 of which were represented by a single individual (e.g., Andira bumilis, Acrocomia aculeata, Calophyllum brasiliense, and Ocotea velutina). The presence of rare or naturally low-density species indicates that new taxa tend to be found as the sample area increases, as demonstrated by Condit et al. (1996).

Regarding the most important species, Tapirira guianensis, has been reported in several studies carried out on different vegetation types and is considered a generalist species (Oliveira-Filho; Fontes, 2000). Siparuna guianensis, the most abundant species in the present study, has been frequently sampled in CER vegetation (e.g., Fina; Monteiro, 2009; Pereira-Silva et al., 2004) and reported in studies carried out on SSF (e.g., Joly, 1994; Silva et al., 2004; Yamamoto et al., 2005).

The basal area of the individuals we found was low (e.g., Toledo Filho et al., 1989; Vieira et al., 1989; Ivanauskas et al., 1999; Costa; Araújo, 2001; Guilherme; Nakajima, 2014). This fact may be related to anthropic disturbances suffered in the past, such as selective cutting, as showed in Figure 2 for the area of the present study. This supports that low basal area values are found in areas with selective cutting history (ALVES et al., 2013).

Many species of our study have wide distribution, occurring in different Brazilian biomes, which was also reported by Gomes et al. (2004) for another ecotonal area. Durigan et al. (2012) highlighted that generalist species with high ecological plasticity are generally abundant in ecotonal 
areas. The predominance of species with wide distribution and the presence of species occurring in both Cerrado and Atlantic Forest reinforce that the area we studied is, in fact, an ecotone. On the other hand, few species are restricted to the Cerrado domain, e.g., Qualea grandiflora, Byrsonima intermedia, and Myrcia bella; and to the Atlantic Forest, e.g., Xylopia brasiliensis, Handroanthus vellosoi, and Pseudobombax grandiflorum (Flora do Brasil, 2020).

The shared species among ecotonal studies (Appendix 4), such as Copaifera langsdorffii, Ocotea corymbosa, Platypodium elegans, Terminalia glabrescens, and Vochysia tucanorum, can be indicator species of Cerrado-Atlantic Forest ecotones from southeastern Brazil (DURIGAN et al., 2012).

Changes in the vegetation type of the study site over time (e.g., Figure 2), with a putative replacement of species of SSF over those of CER, indicate that fire suppression and soil conditions allowed the development of both floristics unities. The ecotonal area, was composed of savannah physiognomies with species of Cerrado (BERTONI et al., 2001; MATTOS; ROCHA, 2002). Currently, it is mainly composed of CER and SSF. Studies have indicated that fire is an important modelling agent in the physiognomies of Cerrado (HENRIQUES, 2005; HOFFMAN; MOREIRA, 2002; PINHEIRO et al., 2021). Fire suppression can replace areas initially occupied by open forms of Cerrado by CER and SSF over the years (DURIGAN et al., 1987; DURIGAN; RATTER 2006). A common action taken in protected areas in Brazil is to extinguish fire events (Monteiro, personal communication), which naturally occur in Cerrado (FIDELIS, 2020).

The analysis of floristic relationships among the compared areas showed a marked distinction between Cerrado and SSF, but placed ecotonal areas closer to the Cerrado or as a subgroup. Although, species of the SSF can colonize areas with fire suppression in Cerrado, the transformation of the vegetation type can be constrained by the soil type (HARIDASSAN, 1992; ROSSI et al., 2005; RODRIGUES et al., 2016; BARROS et al., 2018). Furthermore, we observed a great floristic heterogeneity among the analyzed areas, which included many exclusive and few shared species. Even though communities were sampled in geographically close areas and had the same vegetation types, they had few shared species. Our results support the hypothesis that tropical tree communities have a great floristic heterogeneity over short geographic distances (HUBBEL, 2013; BUENO et al., 2018). In addition, our results indicate that ecotonal tree communities may shelter a heterogeneous species composition and have species from different vegetation types. However, geographically closer communities share more species.

\section{CONCLUSIONS}

In this study, we provided important data about a poorly known vegetation type, corroborating the importance of preserving ecotonal areas for maintaining the high diversity of tropical tree communities. Our data can also help to recognize ecotones between Cerrado and Atlantic Forest from southeastern Brazil and can be used as a floristic reference for future conservation and restorative measures.

\section{ACKNOWLEDGMENTS}

We would like to thank Marco Antonio de Assis and Alessandra Fidelis for all suggestions; and the PFSP employees for the technical support.

\section{REFERENCES}

ALVARES, C. A.; STAPE, J. L.; SENTELHAS, P. C.; GONÇALVES, J. L. de M.; SPAROVEK, G. Köppen's climate classification map for Brazil. Meteorologische Zeitschrift, v. 22, n. 6, p. 711-728, 2013. DOI: $10.1127 / 0941-2948 / 2013 / 0507$

ALVES, H. R.; JÚNIOR, J. A. P.; LOPES, S. F.; SILVA, P. P. F.; PEPPE, F. B.; SCHIAVINI, I. Fitossociologia e grupos ecológicos da comunidade lenhosa em um remanescente de cerradão em Uberlândia, MG. Caminhos de Geografia, v. 14, n. 46, p. 236-245, 2013.

APG IV (Angiosperm Phylogeny Group). An update of the Angiosperm Phylogeny Group classification for the orders and families of flowering plants: APG IV. Botanical Journal of the Linnean Society, v. 181, n. 1, p. 1-20, 2016. DOI: https://doi.org/10.1111/boj.12385

BARROS, M. F.; PINHO, B. X.; LEÃO, T.; TABARELLI, M. Soil attributes structure plant assemblages across an Atlantic forest mosaic. Journal of Plant Ecology, v. 11, n. 4, p. 613-622, 2018. DOI: https://doi.org/10.1093/jpe/rtx037

BATALHA, M. A.; MANTOVANI, W. Floristic composition of the cerrado in the Pé-de-gigante reserve (Santa Rita do Passa Quatro, Southeastern Brazil). Acta Botanica Brasilica, v. 15, n. 3, p. 289-304, 2001. DOI: https://doi.org/10.1590/S0102-33062001000300001

BERNACCI, L. C.; LEITÃO FILHO, H. F. Flora fanerogâmica da Fazenda São Vicente, Campinas, SP. Revista Brasileira de Botânica, v. 19. P. 149-164, 1996. BERTONI, J. E. A.; MARTINS, F. R.; MORAES, J. L.; SHEPHERD, G. J. Composição florística e estrutura fitossociológica do Parque Estadual de Vassununga, Santa Rita do Passa Quatro, SP - Gleba Praxedes. Boletim Técnico do Instituto Florestal, v. 42, p. 149170, 1988.

BERTONI, J. E. A.; TOLEDO FILHO, D. V.; LEITÃO FILGO, H. F.; FRANCO, G. A. D. C.; AGUIAR, O. T. Flora arbórea e arbustiva do cerrado do Parque Estadual de Porto Ferreira (SP). Revista do Instituto Florestal, v. 13, n. 2, p. 169-188, 2001.

BUENO, M. L.; DEXTER, K. G.; PENNINGTON, R. T.; PONTARA, V.; NEVES, D. M.; RATTER, J. A.; OLIVEIRA-FILHO, A. T. The environmental triangle of the Cerrado Domain: Ecological factors driving shifts in tree species composition between forests and savanas. Journal of Ecology, v. 106, n. 5, p. 2109-2120, 2018. DOI: https://doi.org/10.1111/1365-2745.12969

COLWELL, R. K.; CHAO, A.; GOTELI, N. J.; LIN, S.-Y.; MAO, C. X.; CHAZDON, R. L.; LONGINO, J. T. Models and estimators linking individual-based and sample-based rarefaction, extrapolation, and comparison of assemblages. Journal of Plant Ecology, v. 5, n. 1, p. 3-21, 2012. DOI: https://doi.org/10.1093/jpe/rtr044

CAMPOS, E. P.; DUARTE, T. G.; NERI, A. V.; SILVA, A. F.; MEIRA-NETO, J. A. A.; VALENTE, G. E. Composição florística de um trecho de cerradão e cerrado sensu stricto e sua relação com o solo na Floresta Nacional (FLONA) de Paraopeba, MG, Brasil. Revista Árvore, v. 30, n. 3, p. 471-479, 2006.

CONDIT, R.; HUBBEL, S. P.; LAFRANKIE, J. V.; SUKUMAE, R.; MANOKARAN, N.; FOSTER, R. B.; ASHTON, P. S. Species-area and species- individual relationships for tropical trees: a comparison of three 50 - 
ha plots. Journal of Ecology, v. 84, p. 549-562, 1996. DOI: https://doi.org/10.2307/2261477

COSTA, A. A.; ARAÚJO, G. M. Comparação da vegetação arbórea de cerradão e de cerrado na Reserva do Panga, Uberlândia, Minas Gerais. Acta Botanica Brasilica, v. 15, n. 1, p. 63-72, 2001.

COUTINHO, L. M. Fire in the ecology of the Brazilian cerrado. In: GOLDAMMER, J. G. (Ed.). Fire in the tropical biota. Berlin: Springer-Verlag, 1990. p. 81-105.

DURIGAN, G. et al. Fitossociologia e evolução da densidade da vegetação do cerrado de Assis, SP. Boletim Técnico do Instituto Florestal, v. 41, n. 1, p. 59-78, 1987.

DURIGAN, G.; FREITAS, L. F. H.; RODRIGUES, R. R. Phytosociology and structure of a frequently burnt cerrado vegetation in SE-Brazil. Flora, v. 189, n. 2, p. 153-160, 1994. DOI: https://doi.org/10.1016/S03672530(17)30582-0

DURIGAN, G.; SANTOS, J. D.; GANDARA, F. B. Fitossociologia de dois fragmentos de Floresta Estacional Semidecidual no Pontal do Paranapanema, SP. Revista do Instituto Florestal, v. 14, n. 1, p. 13-26, 2002.

DURIGAN, G.; RATTER, J. A. Successional changes in Cerrado and Cerrado/Forest ecotonal vegetation in western São Paulo state, Brazil, 1962-2000. Edinburgh Journal of Botany, v. 63, n. 1, p. 119-130, 2006. DOI: https://doi.org/10.1017/S0960428606000357

FIDELIS, A. Is fire always the "bad guy"?. Flora, v. 268, e151611, 2020.

DOI: https://doi.org/10.1016/j.flora.2020.151611

FINA, F. G.; MONTEIRO, R. Estudo da estrutura da comunidade arbustivoarbórea de uma área de cerradão, município de Pirassununga (SP). Neotropical Biology and Conservation, v. 4, n. 1, p. 40-48, 2009. DOI: http://dx.doi.org/10.4013/5114

Flora do Brasil 2020. Jardim Botânico do Rio de Janeiro. Avaiable from: http://floradobrasil.jbrj.gov.br/

FURLEY, P. A. Edaphic changes at forest savanna boundary with particular reference to neotropics. In: FURLEY, P. A.; PROCTOR, J.; RATTER, J. A. (Eds). Nature and dynamics of forest-savanna boundaries. London: Chapman \& Hall, 1992. 616p.

GARCIA, C. A.; SANTOS, A. G.; BARREIRA, S. Estrutura fitossociológica de uma área de cerrado na estação ecológica de Itapeva, São Paulo, Brasil. Revista de Agricultura Neotropical, v. 2, n. 2, p. 77-85, 2015.

GOMES, B. Z.; MARTINS, F. R.; TAMASHIRO, J. Y. Estrutura do cerradão e da transição do cerradão com a floresta paludícola num fragmento da International Paper do Brasil Ltda., em Brotas, SP. Revista Brasileira de Botânica, v. 27, n. 2, p. 249-262, 2004. DOI: https://doi.org/10.1590/S0100-84042004000200005

GUARATINI, M. T. G.; GOMES, E. P. C.; TAMASHIRO, J. Y.; RODRIGUES, R. R. Composição florística da Reserva Municipal de Santa Genebra, Campinas, SP. Revista Brasileira de Botânica, v. 31, n. 2, p. 323-337, 2008. DOI: https://doi.org/10.1590/S010084042008000200015

GUILHERME, F. A. G.; NAKAJIMA, J. N. Estrutura da vegetação de um remanescente ecotonal urbano florestasavana no Parque do Sabia, em Uberlândia, MG. Revista Árvore, v. 31, n. 2, p. 329-338, 2007. DOI: https://doi.org/10.1590/S0100-67622007000200016

HARIDASAN, M. Observations on soils, foliar nutrient concentration and floristic composition of cerrado sensu stricto and cerradão communities in central Brazil. In: FURLEY, P. A.; PROCTOR, J.; RATTER, J. A. (Eds.). Nature and dynamics of forest-savanna boundaries. London: Chapman \& Hall Publishing, 1992. p.171-184.

HENCKER, C.; ASSIS, A. M.; LIRIO, E. J. Fitossociologia de um trecho de floresta estacional semidecidual no município de Itarana (ES). Natureza On-line, v. 10, n. 3, p.153-159, 2012.

HENRIQUES, R. P. B. Influência da história, solo e fogo na distribuição e dinâmica das fitofisionomias no bioma do Cerrado. In: SCARIOT, A.; SOUSA-SILVA, J. C.; FELFILI, J. M. (Orgs.) Cerrado: ecologia, biodiversidade e conservação. Brasília: Ministério do Meio Ambiente, 2005. 439p.

HOFFMANN, W. A. Ecologia comparativa de espécies lenhosas de cerrado e de mata. In: SCARIOT, A.; SOUSA-SILVA, J. C.; FELFILI, J. M. (Orgs.) Cerrado: ecologia, biodiversidade e conservação. Brasília: Ministério do Meio ambiente, 2005. p. 155-165. (Cap. 8)

HOFFMANN, W. A.; MOREIRA, A. G. The role of fire in population dynamics of woody plants. In: OLIVEIRA, P. S.; MARQUIS, R. S. Ecology and natural history of a neotropical savanna: the cerrados of Brazil. The University of Columbia Press, 2002. p. 159-177.

HUBBELL, S. P. Tropical rain forest conservation and the twin challenges of diversity and rarity. Ecology and Evolution, v. 3, p. 3263-3274, 2013. DOI: https://doi.org/10.1002/ece3.705

INMET_Instituto Nacional de Meteorologia. 2020. Disponível em http://www.inmet.gov.br/portal/index.php?r=home2/i ndex Access: 2020 feb.

IVANAUSKAS, N. M.; RODRIGUES, R. R.; NAVE, A. G. Fitossociologia de um trecho de Floresta Estacional Semidecidual em Itatinga, São Paulo, Brasil. Scientia Forestalis, n. 56, p. 83-99, 1999.

KARK, S.; VAN RENSBURG, B. J. Ecotones: marginal or central areas of transition? Israel Journal of Ecology and Evolution, v. 52, n. 1, p. 29-53, 2006. DOI: 10.1560/IJEE.52.1.29

KONOPCZYK, R. M. G. Composição florística, estrutura e heterogeneidade ambiental da comunidade arbórea de uma várzea em Porto Ferreira, SP, Brasil. 74f. Dissertação (Mestrado em Ciências Biológicas) - Universidade Estadual Paulista, Rio Claro, 2014.

LEGENDRE, P.; LEGENDRE, L. Numerical ecology. v. 24. 3 ed. Amsterdam: Elsevier, 2012. 1006p.

MARTINELLI, G.; MORAES, M. A. (Orgs.) Livro Vermelho da Flora do Brasil. Rio de Janeiro: Centro Nacional de Conservacao da Flora (CNCFLORA), 2013. 1102p.

MUELLER-DOMBOIS, D.; ELLEMBERG, H. Aims and methods of vegetation ecology. New York: John Wiley \& Sons, 1974. 584p.

NETO, O. C. D.; SCHIAVINI, I.; LOPES, S. F.; VALE, V. S.; GUSSON, A. E.; OLIVEIRA, A. P. Estrutura fitossociológica e grupos ecológicos em fragmento de floresta estacional semidecidual, Uberaba, Minas Gerais, Brasil. Rodriguésia, v. 60, n. 4, p. 1087-1100, 2009. DOI: https://doi.org/10.1590/2175-7860200960418

OKSANEN, J.; BLANCHET, F. G.; KINDT, R.; LEGENDRE, P.; MINCHIN, P. R.; O'HARA, R. B.; SIMPSON, G. L.; SOLYMOS, P.; STEVENS, M. H. H.; 
WAGNER, H. Vegan: Community Ecology Package. R Package Version 2.0-10. 2013. Available from: http:/ /vegan.r-forge.r-project.org

ORCZEWSKA, A.; GLISTA, A. Floristic analysis of the two woodland-meadow ecotones differing in orientation of the forest edge. Polish Journal of Ecology, v. 53, n. 3, p. 365-382, 2005.

PASTORE, J. A.; AGUIAR, O. T.; ESTEVES, R.; SILVA, C. A. F. Flora arbóreo-arbustiva do Parque Chico Mendes, município de São Bernardo do Campo (SP). In: Congresso Nacional sobre Essências Nativas, II. Anais... 1992. p. 269-273. Disponível em: https://smastr16.blob.core.windows.net/iflorestal/ifref /RIF4-1/RIF4-1_269-273.pdf

PINHEIRO, M. H. O.; MONTEIRO, R. Contribution of Forest Species to the Floristic Composition of a Forested Savanna in Southeastern Brazil. Brazilian Archives of Biology and Technology, v. 49, n. 5, p. 763-774, 2006. https://doi.org/10.1590/S1516-89132006000600011

PINHEIRO, M. H. O.; MONTEIRO, R. Florística de uma Floresta Estacional Semidecidual, localizada em ecótono savânico-florestal, no município de Bauru, SP, Brasil. Acta Botanica Brasilica, v. 22, n. 4, p. 1085-1094, 2008. https://doi.org/10.1590/S0102-33062008000400019

PINHEIRO, E. S.; DURIGAN, G. Diferenças florísticas e estruturais entre fitofisionomias do cerrado em Assis, SP, Brasil. Revista Árvore, v. 36, n. 1, p. 181-193, 2012. DOI: https://doi.org/10.1590/S0100-67622012000100019

PINHEIRO, M. H. O.; AZEVEDO, T. S.; FERREIRA, F. L.; MONTEIRO, R. Vegetation patterns and the influence of rainfall after long-term fire suppression on a woody community of a Brazilian savanna. Anais da Academia Brasileira de Ciências, v. 93, n. 1, e20191405, 2021. 10.1590/0001-3765202120191405

PIVELlO, V. R.; COUTINHO, L. M. A qualitative successional model to assist in the management of Brazilian cerrados. Forest Ecology and Management, v. 87, p. $127-138,1996$.

R Core Team (2020). R: A language and environment for statistical computing. R Foundation for Statistical Computing, Vienna, Austria. Available from: https://www.R-project.org/

RATTER, J. A. Transition between cerrado and forest vegetation in Brazil. In: FURLEY, P. A.; PROCTOR, J.; RATTER, J. A. (Eds). Nature and dynamics of forestsavana boundaries. London: Chapman \& Hall, 1992. 616p.

RIBAS, R. F.; NETO, J. A. A. M.; SILVA, A. F.; SOUZA, A. L. Composição florística de dois trechos em diferentes etapas serais de uma floresta estacional demidecidual em Viçosa, Minas Gerais. Revista Árvore, v. 27, n. 6, p. 821 830, 2003. DOI: https://doi.org/10.1590/S010067622003000600008

RISSER, P. G. Ecotone at local to regional scales from around the world. Ecological Applications, v. 3, n. 3, p. 367-368, 1993. DOI: $10.2307 / 1941904$

RODRIGUES, P. M. S.; SCHAEFER, C. E. G. R.; SILVA, J. O.; JÚNIOR, W. G. F.; SANTOS, R. M.; NERI, A. V. The influence of soil on vegetation structure and plant diversity in different tropical savannic and forest habitats. Journal of Plant Ecology, v. 11, n. 2, p. 226-236, 2016. DOI: https://doi.org/10.1093/jpe/rtw135

ROSSI, M.; MATTOS, I. F. A.; COELHO, R. M.; MENK, J. R. F.; ROCHA, F. T.; PFEIFER, R. M.; DEMARIA, I.
C. Relação solos/vegetação em área natural no Parque Estadual de Porto Ferreira, São Paulo. Revista do Instituto Florestal, v. 17, n. 1, p. 45-61, 2005.

SAUER, J. D. Plant migration. The dynamics of geographic patterning in seed plant species. Berkley: Univesity of California Press, 1988. 282p.

SCHILTHUIZEN, M. Ecotone: Speciation-prone. Trends in Ecology \& Evolution, v. 15, p. 130-13, 2000. DOI: https://doi.org/10.1016/S0169-5347(00)01839-5

SCHLUTER, D. The ecology of adaptive radiation. Oxford: University Press, 2000. 288p.

SHEPHERD, G. J. FITOPAC 2: Manual do usuário. Departamento de Botânica. UNICAMP, Campinas. 2008. 78p.

SILVA, J. M. C.; BATES, J. M. Biogeographic patterns and conservation in the South American Cerrado: A Tropical Savanna Hotspot. Bioscience, v. 52, n. 3, p. 225-233, 2002. DOI: https://doi.org/10.1641/00063568(2002)052[0225:BPACIT]2.0.CO;2

SILVA, L. A.; SOARES, J. J. Composição florística de um fragmento de floresta estacional semidecídua no município de São Carlos-SP. Revista Árvore, v. 27, n. 5, p. 647-656, 2003.

SILVA, E. F. L. P.; SANTOS, J. E.; KAGEYAMA, P. Y.; HARDT, E. Florística e fitossociologia dos estratos arbustivo e arbóreo de um remanescente de cerradão em uma Unidade de Conservação do Estado de São Paulo. Revista Brasileira de Botânica, v. 27, n. 3, p. 533-544, 2004.

SMITH, T. B.; KARK, S.; SCHNEIDER, C. J.; WAYNE, R. K.; MORITZ, C. Biodiversity hotspots and beyond: the need for conserving environmental transitions. Trends in Ecology and Evolution, v. 16, n. 8, p. 431, 2001. DOI: https://doi.org/10.1016/S0169-5347(01)02201-7

TEIXEIRA, M. I. J. G.; ARAUJO, A. R. B.; VALERI, S. V.; RODRIGUES, R. R. Florística e fitossociologia de área de cerrado S.S. no município de Patrocínio Paulista, nordeste do Estado de São Paulo. Bragantia, v. 63, n. 1, p. 1-11, 2004. DOI: https://doi.org/10.1590/S000687052004000100001

The Plant List. 2020. Version 1.1. Published on the Internet; avaible from: http://www.theplantlist.org/ Accessed on feb, 2020.

TOLEDO FILHO, D. V.; LEITÃO FILHO, H. F.; SHEPHERD, G. J. Estrutura fitossociológica da Vegetação de um Cerrado em Mogi Mirim (SP). Revista do Instituto Florestal, v. 1, n. 2, p. 1-12, 1989.

TOLEDO FILHO, D. V.; LEITÃO FILHO, H. F.; BERTONI, J. E. A.; BATISTA, E. A.; PARENTE, P. R. Composição florística do estrato arbóreo da Reserva Estadual de Águas da Prata (SP). Revista do Instituto Florestal, v. 5, n. 2, p. 113-122, 1993.

Tropicos. 2020. Available from: www.tropicos.org. Missouri Botanical Garden. Accessed: 2020 Feb.

Van der MAAREL, E. On the establishment of plant community boundaries. Berichte der Deutschen Botanischen Gesellschaft, v. 89, p. 415-443, 1976.

VIEIRA, M. G. L.; MORAES, J. L.; BERTONI, J. E. A.; MARTINS, F. R.; ZANDARIN, M. A. Composição florística e estrutura fitossociológica da vegetação arbórea do Parque Estadual de Vaçununga, Santa Rita do Passa Quatro (SP). II-Gleba Capetinga Oeste*. Revista do Instituto Florestal, v. 1, n. 1, p. 135-159, 1989. 


\section{APPENDIX}

Appendix 1. Numbers of species reported exclusively in this and each one of the previous studies. Co: code; Vt: vegetation type; E ssp.: number of exclusive species; Ssf: seasonal semideciduous forest; Cd: cerradão; C ss: cerrado sensu stricto.

Apêndice 1. Número de espécies exclusivas entre os estudos selecionados para a análise de similaridade florística. Co: código; Vt: Fitofisionomia; E spp: número de espécies exclusivas; Ssf: floresta estacional semidecidual; Cd: cerradão; C ss: cerrado sensu stricto.

\begin{tabular}{clcc}
\hline Co & Reference & Vt & E spp. \\
\hline A & Present study & Ecotone & 5 \\
B & Pinheiro \& Monteiro 2008 & Ecotone & 30 \\
C & Gomes et al. 2004 & Ecotone & 10 \\
D & Guilherme \& Nakajima 2007 & Ecotone & 14 \\
E & Ribas et al. 2003 & Ssf & 32 \\
F & Bernacci \& Leitão 1996 & Ssf & 21 \\
G & Guaratini et al. 2008 & Ssf & 22 \\
H & Bertoni et al. 1988 & Ssf & 1 \\
I & Vieira et al. 1989 & Ssf & 0 \\
J & Ivanauskas et al. 1999 & Ssf & 16 \\
K & Pastore et al. 1992 & Ssf & 24 \\
L & Silva \& Soares 2003 & Ssf & 18 \\
M & Toledo Filho et al. 1993 & Ssf & 20 \\
N & Alves et al. 2013 & Cd & 1 \\
O & Batalha \& Mantovani, 2001 & Cd & 6 \\
P & Silva et al. 2004 & Cd & 4 \\
Q & Pinheiro \& Monteiro 2006 & Cd & 1 \\
R & Toledo Filho et al. 1989 & Cd & 7 \\
S & Costa \& Araújo 2001 & Cd, C ss & 5 \\
T & Campos et al. 2006 & Cd, C ss & 7 \\
\hline
\end{tabular}

Appendix 2. Species occurring in $10(50 \%)$ or more lists among the compared studies and PFSP. N: number of lists in which the species occurs.

Appendix 2. Espécies com ocorrência igual ou superior a 10 listas $(50 \%)$ entre os estudos selecionados para a análise de similaridade florística. $\mathrm{N}$ : número de listas com ocorrência.

\begin{tabular}{lll}
\hline \multicolumn{1}{c}{ Species } & N & $\%$ \\
\hline Roupala montana Aubl. & 18 & 90 \\
Copaifera langsdorffii Desf. & 16 & 80 \\
Qualea multiflora Mart. & 16 & 80 \\
Tapirira guianensis Aubl. & 14 & 70 \\
Casearia sylvestris Sw. & 13 & 65 \\
Myrcia splendens (Sw.) DC. & 13 & 65 \\
Ocotea corymbosa (Meisn.) Mez & 13 & 65 \\
Vochysia tucanorum Mart. & 13 & 65 \\
Siparuna guianensis Aubl. & 12 & 60 \\
Dimorphandra mollis Benth. & 11 & 55 \\
Lafoensia pacari A.St.-Hil. & 11 & 55 \\
Miconia albicans (Sw.) Triana & 11 & 55 \\
Myrcia tomentosa (Aubl.) DC. & 11 & 55 \\
Myrsine umbellata Mart. & 11 & 55 \\
Pera glabrata (Schott) Baill. & 11 & 55 \\
Plathymenia reticulata Benth. & 11 & 55 \\
Platypodium elegans Vogel & 11 & 55 \\
Qualea grandiflora Mart. & 11 & 55 \\
Rudgea viburnoides (Cham.) Benth. & 11 & 55 \\
Xylopia aromatica (Lam.) Mart. & 11 & 55 \\
Bowdichia virgilioides Kunth & 10 & 50 \\
Brosimum gaudichaudii Trécul & 10 & 50 \\
Caryocar brasiliense Cambess. & 10 & 50 \\
Croton floribundus Spreng. & 10 & 50 \\
Protium heptaphyllum (Aubl.) Marchand & 10 & 50 \\
Terminalia glabrescens Mart. & 10 & 50 \\
\hline & &
\end{tabular}

Appendix 3. Numbers of exclusive species among the studies carried out on ecotonal vegetation. Co: code; Vt: vegetation type; E ssp.: number of exclusive species; Ssf: seasonal semideciduous forest; Cd: cerradão; C ss: cerrado sensu stricto.

Apêndice 3. Número de espécies exclusivas entre os estudos selecionados para a análise de similaridade florística. Co: código; Vt: fitofisionomia; E spp: número de espécies exclusivas; Ssf: floresta estacional semidecidual; Cd: cerradão; C ss: cerrado sensu stricto.

\begin{tabular}{clcc}
\hline Co & \multicolumn{1}{c}{ REFERENCE } & Vt & E spp. \\
\hline A & Present study & Ecotone & 18 \\
B & Pinheiro \& Monteiro 2008 & Ecotone & 125 \\
C & Gomes et al. 2004 & Ecotone & 30 \\
D & Guilherme \& Nakajima 2007 & Ecotone & 46 \\
\hline
\end{tabular}

Appendix 4. Shared species among ecotonal vegetation lists. Apêndice 4. Espécies compartilhadas nas listas de vegetação ecotonal.
Species
Casearia sylvestris $\mathrm{Sw}$.
Copaifera langsdorffii Desf.
Dimorphandra mollis Benth.
Myrcia tomentosa (Aubl.) DC.
Myrsine umbellata Mart.
Ocotea corymbosa (Meisn.) Mez
Pera glabrata (Schott) Baill.
Platypodium elegans Vogel

Protium heptaphyllum (Aubl.) Marchand

Qualea grandiflora Mart.

Roupala montana Aubl.

Rudgea viburnoides (Cham.) Benth.

Siparuna guianensis Aubl.

Styrax camporum Pohl

Tapirira guianensis Aubl.

Terminalia glabrescens Mart.

Vochysia tucanorum Mart.

Xylopia aromatica (Lam.) Mart.

Zanthoxylum rboifolium Lam. 